\title{
TAKĀFUL: CONCEPT, HISTORY, DEVELOPMENT, AND FUTURE CHALLENGES OF ITS INDUSTRY
}

\author{
Syed Othman Alhabshi and Shaikh Hamzah Shaikh Abdul Razak*
}

\begin{abstract}
Mutual help and guarantee have been the ordinary practice of tribal Arabs even before the advent of Islam in Arabia. A similar but refined concept was reinforced by the Qur'ān to be adopted by Muslims. It was widely applied in their daily lives. When the Muslims extended their trade by sea to the Far East, the concept of mutual assistance became more prominent and organised to protect their ships, merchandise and even lives from all sorts of dangers and mishaps. The practice by these merchants to put aside a sum of money before setting sail to the Far East for trade as a fund to compensate any loss incurred by any of them became the most prominent practice that led to the birth of what is today known as marine insurance. To circumvent some of the sharīah non-compliant practices of mainstream insurance is the introduction of the concept of donating part of the participants' contribution which forms the special fund to compensate losses. From then on, the takāful operators started to emerge, first in Sudan and later in other parts of the Muslim world. Several models have been formulated, namely muḍārabah, modified muḍārabah, wakālah and wakālah-waqf. The success of the takāful companies around the world has also been strongly influenced by the recent upsurge in the petroleum price that has led to the unprecedented increase in sovereign and private wealth. The recent emergence of 're-takāful' companies add up further to the rapid growth in takäful operators and funds. Despite the success stories, there are a number of serious challenges facing takāful and 're-takāful' operators which are worth noting.
\end{abstract}

\section{Introduction}

Takäful is derived from its Arabic root kafala which literally means 'to guarantee'. In terms of usage and implication, the term kafälah denotes the agreement by one party to indemnify another for any liability that has been pre-agreed upon.

* Prof. Dr Syed Othman Alhabshi is Professor of Islamic Economics and Econometrics and Dean of the Takâful Faculty at the International Centre for Education in Islamic Finance (INCEIF), Kuala Lumpur. Shaikh Hamzah Shaikh Abdul Razak is a Lecturer in the Takäful Department of the International Centre for Education in Islamic Finance (INCEIF), Kuala Lumpur. 
The takâful industry is only 30 years old, the first company being established in 1979 in Sudan. After about two decades, it has proven to be the fastest growing sector of the insurance market with an unprecedented double digit rate of sustainable growth for several consecutive years. ${ }^{1}$ Muhammad bin Ibrahim, the Assistant Governor of Bank Negara Malaysia, Malaysia’s central bank, stated:

Based on the 2007 Oliver Wyman Report, the potential premium for takāful worldwide, is at least US\$20 billion. The report also estimates that up to 20 per cent of the takāful revenues originated from non-Muslim customers. [...] Currently there are more than 250 takāful operators worldwide. ${ }^{2}$

The participation of established conventional players in the United Kingdom, the United States, and Germany in establishing both the takāful and 're-takäful' companies within their group is indeed a crucial contributor to the growth of takäful industry worldwide.

In addition, the global demand for takâful products continues to grow as a consequence of the phenomenal growth of various components in the Islamic financial system especially the Islamic banking and capital market sectors. This is evidenced by the tremendous growth in Islamic financing and mortgages in the Islamic banking sector and increasing popularity of şukuk issuance in the Islamic capital market. ${ }^{3}$

The industry is further supported by progress in the regulatory sphere in the last two years. The Islamic Financial Services Board (IFSB), in collaboration with the International Association of Insurance Supervisors, is actively involved in the development of standards applicable to takaful. They are also looking at the corporate governance standard to cover key issues in the takäful business including rights and obligations of stakeholders in takäful operations. ${ }^{4}$

Conventional insurance companies operate on the basis of a guarantee to the policy holders that they will undertake to compensate them against any loss incurred as per their contract. In this sense there is no material difference between the practices of a conventional insurer to those of the takâful operators. Both are dealing with indemnifying their customers and paying out compensation to the losses incurred by the customers. What then are the real differences between conventional insurance and takafful that have led to the separate, dramatic development of the takâful industry the world over in the last three to four decades? Are these differences based on the concept and principles or are they simply operational?

Unlike Islamic banking that basically meanders away from usury or rib $\bar{a}$ in order to make the products and operations sharī'ah-compliant, takäful can easily avoid rib $\bar{a}$ by not investing in rib $\bar{a}$-based instruments that are now available in the Islamic capital and money markets. What else are the main differences between conventional insurance and takāful? In order to fully appreciate what takāful entails 
and how it operates to become sharī'ah-compliant, we need to understand the underlying principles that make takäful not only sharì 'ah-compliant but operational as a business concern as well.

Before we examine the sharī'ah-principles on takāful, it is helpful to understand some of the ancient Arab practices that were akin to the takāful operations today. This article will expound these principles and practices, how they were endorsed by the Prophet Muhammad himself, and then supported by the Qur'ān. We shall also illustrate the concepts and principles employed by modern takâful operators in order to operationalise their models. Finally, the article takes a brief look at some of the issues and challenges that still plague these models and the industry as a whole.

\section{Pre-Islamic Practices of Kafālah}

The concept of kafālah has been in vogue well before the advent of Islam. It is generally known that the ancient Arabs practised a strong tribal system which took great pride in lineage and ancestry. There was no compromise when the good name of the ancestors were being ridiculed or defamed. If a member of the tribe committed murder, for instance, it could lead to one of two consequences. Either a tribal war broke out to avenge the death of the tribal member, or settlement was reached by paying 'blood money'. The money that was used to compensate the loss of life came from the tribal fund which was collected from donations by the members. Once the donation was collected, no refund was allowed. The fund was used mainly to settle compensation in tribal disputes. It could also be collected when a dispute had occurred or whenever the fund was depleted. This practice is known as al- 'aqilah. This cooperation on the part of the whole group and community to mutually share the burden of any of its members reflects the spirit of mutuality in takâful. The payment of blood money was an obvious example of mutual insurance, wherein the whole community stood guarantee against the loss to any of its members. This communal enterprise was social in character but economic in consequence. ${ }^{5}$ Accoding to one study, "[t]he underlying principle in mutual insurance is that the individual members are themselves the insurers as well as the insured". 6

\section{The Principle of Mutuality and Islam}

In the pre-Islamic period, payment of blood money by the family or tribe of the killer as compensation to the family or tribe of the killed was commonplace. The individual killer was generally responsible for the payment of the compensation. However, the common practice was for his family or tribe to pay the compensation. As the members of each tribe were closely related and united to face the common dangers of desert life, they developed an extreme sense of loyalty to their tribe. 
Each tribe tried to protect and safeguard the life and property of its members. Gradually, this group loyalty and the inter-dependence of its members developed into mutuality and manifested itself in the form of collective responsibility of the tribe to pay compensation for the killing of a member of another tribe by one of its own members. The payment could be in the form of cash or kind, such as camels. The principle of compensation in cash or kind had four outstanding benefits for the people of Arabia:

- it reduced bloodshed and blood-feuds in the country;

- it replaced individual responsibility with the ultimate collective responsibility of the tribe for the actions of its members, and thus helped achieve social security for individual members of each tribe;

- it reduced the financial burden of the individual by transferring it to the group; and

- it developed a spirit of cooperation and brotherhood among the members as reflected in mutuality to share the individual burden amongst the group. ${ }^{7}$

\section{The Practice After the Advent of Islam}

With the advent of Islam, the same practice was continued due to its benefits as is evident from certain injunctions in the Qur'ān. ${ }^{8}$ Qur'ānic evidence clearly supports the practice of paying compensation in terms of 'blood money' (al-diyyah) although the law of equality allows revenge only to the same extent. Equality is mainly intended to mitigate the horrors of the pre-Islamic custom of retaliation and revenge. In order to meet the strict claims of justice, equality is prescribed, with a strong recommendation for mercy and forgiveness.

Islam also mitigated the horrors of the pre-Islamic retaliation in wounds and injuries by prescribing the law of equality in all such cases. ${ }^{9}$ Again forgiveness and mercy, instead of retaliation, is strongly recommended in order to avoid bloodshed in the community. Al-diyyah was also reinforced by the Prophet who permitted it as compensation for human life, stating that the value or quantum must be agreed upon and the money must come from the family of the party that committed the killing.

The same provision was included in the first Islamic constitution of Medina. Through the practice of al-diyyah, the money was supposed to be paid mutually by the al-'a qilah (the close relatives of the killer) to the heir of the deceased (victim). ${ }^{10}$ In view of the support by the tribe, the murderer was exempted from criminal prosecution even though the relatives were unable to pay.

These injunctions are further supported by a famous hadīth, narrated by Abū Hurayrah, ${ }^{11}$ which in essence calls for uplifting the hardships of others instead of 
pressing charges, although the law of equality allows such revenge as per qur'ānic stipulations.

Moreover, 'Umar b. al-Khatțāb, the second caliph of Islam (r. 634-44), directed all districts of the state to list the name of the Muslim brothers-in-arms and the people who owed each other to contribute blood money in the event of any manslaughter committed by anyone of their own tribe.

By the end of the eighth century CE, the Muslims had developed marine science, marine navigation, and had built a strong naval unit in the Mediterranean. According to Philip Hitti, 'Abd al-Raḥmān III (r. 912-61), the famous Spanish Umayyad ruler, was the founder of the Muslim navy in Al-Andalus. He appointed his first Chamberlain, Tammām, as its commander. Tammām thus became the first Muslim admiral in Europe. Also under 'Abd al-Raḥmān III, this Arab navy became the most powerful in the Western Mediterranean. The fact remains, however, that Spain, under Islam reached economic and cultural heights unattained before, and its capital vied with Constantinople and Baghdad as a world centre of grandeur, affluence and enlightenment. Arab writers even styled Cordova the 'bride of all Andalus' and an Anglo-Saxon nun referred to it the 'Jewel of the world'. ${ }^{12}$

It was during these voyages that the merchants felt the need for insurance to cover their losses through the perils of the sea. Based on the principle of 'helping one another' they contributed to a fund prior to starting their voyage and used it to compensate any of them who incurred losses. This was the start of marine insurance which of course has been much modified today.

The principle that these Muslim merchants employed as is enjoined by the Qur'ān is based on the verse that reads, "Help ye one another unto righteousness and pious duty. Help not one another unto sin and transgression, but keep your duty to Allah." 13 This principle of helping one another is amply demonstrated by the practice of al- 'aq ilah of the pre-Islamic period and hence it became acceptable to Islam.

\section{The Concept of Takäful}

We can discern from the above account of the pre-Islamic practices that takaful is based on a mutual intention of protecting one another against common dangers. This is possible if the members of the group feel for themselves as much as they feel for the others. So much so, if any one of them is inflicted with any harm or danger, the whole group feels the pain. In this way, the whole group or community will feel obliged and responsible to help one another so that the burden is not shouldered by any one person but by each and every member. If anyone is inflicted with harm the whole group or community feels it so. By working as a group in facing the risks or dangers, the burden becomes much lighter. The bigger the size of the group the lighter is the burden or liability. 
Such a feeling of responsibility is being reinforced by the Islamic teachings as found in the Qur'ān, as already reviewed. The Prophet, too, made several very well-known statements on the responsibility of Muslims to help each other:

- "Allah will always help His servant for as long as he helps his brother [in need]", ${ }^{14}$

- "The believers are like the body; when one of its parts is afflicted with pain, the rest of the body will also be affected", ${ }^{15}$

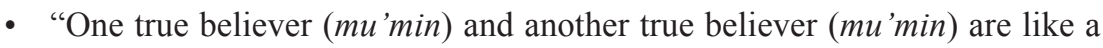
building whereby every part in it strengthens the other part,"

- "By my life, which is in Allah's power, nobody will enter Paradise if he does not protect his neighbour who is in distress". ${ }^{17}$

Based on the above, the principles of takâful may be summarised as follows:

- policy holders cooperate among themselves for their common good;

- every policy holder pays his subscription to help those that need assistance;

- losses are divided and liabilities spread according to the community pooling system;

- uncertainty is eliminated in respect of subscription and compensation;

- advantage is not derived at the cost of others.

Essentially takâful is a cooperative insurance whereby members who face the same risk or danger of incurring losses willingly contribute a certain sum of money which will be used to compensate those members of the group who incur such losses. As in the case of ancient Arab tribal custom, every member of the tribe faced the same danger of being harmed by another warring tribe.

In the case of the modern motor policy, for instance, everyone who drives a vehicle on the road faces the risk of an accident. The most logical step to take is to invite these people who face the common danger to form a group and contribute a sum of money which can be used to compensate any of the members who incur losses due to an accident. The same principle is applied to marine, fire, etc.

\section{Differences Between Takāful and Conventional Insurance}

In conventional insurance, the company sells a policy to the insured who pays a premium for the risk he agrees to be indemnified against by the company or insurer. The policy will not only determine the kind of risk that is covered but also the kinds of risks that are excluded, the period of coverage for the indemnity, the limit of compensation that the insured will get, and sometimes the level of damage or 
loss that the company will not be responsible for. When the insured has incurred a loss that arises from an event that is defined by the policy, the company will pay or cover the losses incurred. If nothing happens during the period under cover, the company takes all the money or premium that has been paid up front.

It is clear from the conventional practice that the contract is one of sale and purchase. The company sells the policy to the insured at a price which is the premium. The company then basically takes chances that it will indemnify the insured up to some limit based on the premium that has been paid. However, the insured does not get any benefit except an undertaking as stated in the policy that the company will take care of his losses when the risk materialises. If the risk does not materialise during the period under cover, the company takes all the premium and the insured gets nothing.

Based on the above practice, the Muslim jurists unanimously concluded that while the objective of the insurance is good, the manner it is conducted is not shari 'ahcompliant. The first objection is the presence of the element of chance taken by the company. Of course this is done on the basis of some historical knowledge about the probability of an event happening which follows the law of large numbers. However, a game of chance necessarily creates an ambiguous situation. There is no certainty in the outcome of the contract. Ambiguity in contract is not acceptable in Islam as it could subject either of the two parties to injustice. Ambiguity of this type is called gharar which could vitiate the contract when it is excessive.

The second objection is the element of maysir or gambling that arises out of the chance phenomenon that exists in the contract. The insured takes a chance to protect himself from the risk he is facing. He is prepared to lose the premium if the risk does not materialise. But if the risk materialises, he will get much more than the premium he has paid. This means one party getting something more than he paid for based on chance, which is akin to gambling and thus prohibited by the shari 'ah.

The third element is rib $\bar{a}$ or usury that is present in the form of returns from the investment of the insurance fund. Since most of the investments are placed in interest-based instruments hence it is prohibited by the sharī $a h$.

These are the three main objections raised by the Muslim jurists which make it necessary for the jurists to formulate shari ${ }^{-} a h$-compliant models. The main reason is that insurance is a necessity and benefits the community. Based on a well-known hadīth, narrated by 'Āmir b. Sa 'd b. Abī Waqqāṣ, it is clear that it is better to leave behind wealth that would enable one's loved ones to lead a good life than to leave them with nothing to depend on. In this hadīth 'Āmir's father Sa 'd reported that he was taken seriously ill in the year of the Prophet's final pilgrimage and the Prophet visited him to enquire about his health. Sa 'd told him about his worries in case he should die. Sa'd enquired from the Prophet whether he should give two-thirds of 
his property to charity. In reply, the Prophet told him that it would be better to leave his inheritors wealthy rather than to leave them in poverty and beg from others. ${ }^{18}$

Similarly, another famous hadìth, narrated by Anas b. Mālik, reports that the Prophet once told a Bedouin Arab who left his camel untied trusting to the will of God to tie the camel first then leave it to God. ${ }^{19}$ This reinforces the need to take every precaution to secure one's property instead of just leave it to chance and hope that God will protect it. We should not leave the fate of our children or property to chance. Rather, we should work hard to secure them and only then should we leave their safety to the will of Allah.

\section{Takāful Operations}

Takâful operators must conduct their business in a sharī'ah-compliant way by avoiding the three prohibited elements above that make the operations void. The easiest part is to avoid rib $\bar{a}$, by investing the takafful fund in non-interest-bearing instruments. The question is how to avoid the first two, i.e. gharar or ambiguity and uncertainty and maysir or gambling. If we refer to the qur'ānic injunction quoted above $^{20}$ on the principle of ta $\bar{a}$ wun (cooperation) which is that people should help one another in righteousness and piety, we can invite people, especially those who face the same danger or take the same risk to come together and form a group that is willing to help one another. In other words, if anyone among them incurs a loss caused by an event that has been agreed upon, all the members of the group agree to help the unfortunate individual. Based on this understanding, a fund can be created from the contributions of each member on the basis of donation or tabarru'. This is probably the most important concept that has been applied in all takäful models.

Based on the principles of ta 'âwun and tabarru', the company is then simply the operator that invites people who face the same risk to form that group. The company is not selling a policy as such and does not indulge in the prohibited elements of gharar and maysir. Rather, the company is an operator that makes arrangements for the group to come together and agree not only to contribute to the fund but also at the same time agree to donate at least part of the fund to any member of the group who has become victim of any peril or mishap that has been identified earlier.

This is exactly what the ancient Arab tribal system did. So did the Muslim merchants of the eighth century who collected a sum of money as a donation to be used as compensation to any of them who faced mishap and incurred losses. There is complete transparency in this case so as to avoid all ambiguities or chances. Thus the company does not own the fund but the ownership of the fund remains with the policy holders or participants as they are called by the takäful industry.

In this sense, the company is not taking the risk, but it is the group of participants who bear the risk and are mutually covering each other. The company is only a 
trustee acting on behalf of the participants to manage the operation of the takâful business. As such, the company does not have any right to the takaful benefits. However, as an operator or manager of the takaful business, the company is the entrepreneur or mudārib whilst the participants are the provider of capital or $r a b b$ $a l-m \bar{a} l$ as in the case of the mudārabah concept. In this sense, the profits made from the business can be shared by both parties at a pre-agreed ratio.

Based on the above concept, there are at least two ways that the company can operate as a business. The first is to employ the mudārabah or profit sharing model. The second is to employ the wakälah or agency model. There are other models such as the modified mudārabah model and wakālah-waqf model which are variants of the two basic models.

\section{The Muḍārabah Model}

The mudārabah model consists of two parties, namely the provider of capital or rabb al-māl on the one hand, and the entrepreneur or mudārib who provides the management expertise and entrepreneurial acumen to the business, on the other. These two parties will share the profits after deducting all the expenses to conduct the business at a pre-agreed ratio. However, in case of a loss, it is only the provider of capital who assumes the losses. The entrepreneur does not assume any liability in case of a loss because he has already provided the expertise without any payment.

The mudārabah or profit sharing model as employed by the takāful operators is where the company operates as an entrepreneur or mudārib, utilising its expertise in the general management of the company, underwriting the policies and investing the funds. General management also includes functions such as product development, marketing, human resource, corporate planning, compliance and governance, etc. The contributions paid by the participants are deemed to belong to the participants, and hence they as a group are considered to be the provider of capital or rabb $a l-m \bar{a} l$ in the mudārabah model. The profit arising out of the whole operation after deducting the expenses incurred to conduct the business is to be divided between the company and the participants at a pre-agreed ratio. In some cases, the cost of doing business is deducted from the share of the profits of the entrepreneur.

The question is that the management and staff of the company are salary earners and hence are not in sync with the concept of entrepreneur in the mudārabah model. It should be clarified that they are paid out of the shareholders' fund and not out of the income of the business. Hence, they represent the entrepreneur in the mudārabah model. Alternatively, the management expenses are being deducted from the share of gross profits to the shareholders. In other words, the total profit from investment and underwriting surplus is being shared according to the pre-agreed ratio. It is from the share of the profit to the shareholders that the management expenses are 
being deducted. In this way, whether the management expenses are being borne by the shareholders from the shareholders' fund or from the share of the profit, the consequence is the same.

With this conception, the company then has the right not only to a share of the profits from the investment income of the takâful fund accumulated from the participants' contributions, but also to share in management of the business.

In any takäful operation, whether the company employs the mudatrabah or wakālah model, there are basically three funds, namely the shareholders' fund, the takâful fund comprising the Participants' Account, and tabarru 'or donation or the Participants' Special Account (PSA). Whilst the shareholders' fund literally belongs to the shareholders, the takäful funds actually come from the participants' contributions and hence belong to the participants. The allocation of the participants' contributions into these two funds is done based on actuarial studies. For products with higher risk or claims ratio, a higher proportion of the contribution will be placed in the tabarru' fund to ensure that there are enough funds to cover the claims. It is only when the product has a lower risk or claims ratio that a higher proportion of the contribution will be allocated to the takāful fund.

Given these three funds, there should be two main sources of income to the takâful company, namely the investment income and the underwriting surplus. The investment income from the shareholders' fund will obviously go back to the shareholders. Logically, as an entrepreneur, the company has the right to a share in the investment income from the Participants' Account and tabarru funds or the Participants' Special Account. What seems to be contentious is the underwriting surplus.

One view is that the surplus from the underwriting activity cannot be shared by the company because it is a donation by the participant to pay out the claims. There is another view that the underwriting activity is done by the company with all its expertise and hence should be able to have a share of it as a provider of that expertise.

However, the general view seems to be that the surplus should not be paid out to the participants either, since they have already donated the amount for the purpose of paying out the claims. Under the principle of tabarru' or donation, the donor has completely given away his right to the property or wealth that he has donated and therefore cannot receive any benefit from it.

The question may be raised as to how he can receive the claim payment to the loss that he incurs in the process. The concept here is that every individual participant pledges to help others with his own donation. His donation is meant for others and not for himself. With a large number of participants, it is possible that he does not receive his money back, but whatever he receives will be the donations made by others. 


\section{General Takäful Business}

For conventional insurance, there are basically two categories namely the general and life. The same is true in takâful where there is the general, but instead of life it is called family takāful. The general takāful business deals mainly with specific contingencies such as fire, accident and theft. General takâful normally covers a specific short period of one year and is to be renewed annually to ensure its validity.

In the case of the general takäful business under the mudārabah model, the company shares the profits from investments as well as from the underwriting surplus. However, all the administrative and management expenses are deducted from the company's share of the profits and surplus. In the case of the modified mudāarabah model for general takâful, the commissions to intermediaries and management expenses are paid from the takâful fund. The company shares the profit and the underwriting surplus with the participants.

\section{Family Takāful Business}

A life insurance contract insures the life of a person. Once it is sold, the company is liable to pay only upon the policy holder's death. Since the majority of jurists do not approve that life insurance as defined here is sharī'ah-compliant, the takâful companies use the term family takāful instead. Family takāful, unlike life insurance, does not insure the life of the person who buys the policy. Instead, it is meant to provide a lump sum payment to the family of the deceased, to help them survive for some time without much sacrifice in life style.

For the family takâful business under the mudārabah model, the company does not share the underwriting surplus but returns it to the participants to be accumulated to build the fund. The company only shares the investment profits and deducts all administrative and management expenses from the shareholders' share of the profits from investment.

Under the modified mudārabah model, the company not only shares the investment income from both the Participants' Accounts and the Participants' Special Accounts but also deducts the Commission and Management Expenses from the Participant's Special Accounts. Of course the share of the profits for the company under the modified mudārabah model is smaller compared to those of the mudārabah model.

\section{The Wakālah Model}

The wakâlah model is currently the most commonly used model in most countries. Although the takafful companies which were established in the 1980s employed the mudāarabah or the modified mudārabah models, the newly established companies in the last three or four years have chosen to employ the wakālah model. 
Wakālah, which literally means 'agency', employs the sharī 'ah principle of providing a service for a fee or ujr. In a wakālah model, the takāful operator acts as the agent on behalf of the participants. The operator is paid a pre-agreed management fee for the services rendered in respect of underwriting, management and investment of the fund. The operator does not share in the underwriting surplus. This is mainly because the contributions by the participants allocated to the Participants' Special Accounts are based on tabarru' or voluntary donation which according to the shari 'ah cannot benefit the contributor anymore. The proceeds from the underwriting surplus are being ploughed back into the fund.

In underwriting, the takâful operator acts as an agent on behalf of the participants to manage the takâful fund. Any liabilities for risks underwritten are borne by the fund and any surplus arising from there belongs exclusively to the participants. The operator is not liable for any deficit of the fund. The operator is being paid a management fee termed as a wakälah fee which is usually a percentage of the contributions paid by the participants. This is normally deducted upfront from the contributions.

As for the management of the investment activities of the fund, the operator is also paid a wakālah fee based on an agreed percentage. Alternatively, the operator may take a share of the profit if it considers the service provided as part of the expert service to manage the fund. When the fund is still very small, the company may opt to do it in-house. Obviously, when the fund has grown very big, the operator may need to outsource the responsibility of managing the fund to an outside party. This approach would certainly attract additional costs to the company, otherwise.

\section{General Takāful Business}

According to this variant, the contributions from participants in the general takâful business under the wakälah model are put into the General Risk Investment Account (GRIA) which is also known as the General Fund. Upon receipt of the contributions from the participants, the company charges a wakālah fee for managing this fund. Part of the contributions in GRIA are then placed in the Ta 'a wuni Account Pool (TAP) that has front-and-back-end charges as allocations for benefits/reserves, claims, servicing, management expenses and commission (Expense Fund, Risk Fund and Special Fund). The TAP is essentially another name for the tabarru' fund that is used for the payment of claims. Any surpluses in TAP will be put back into the GRIA. The company will charge a Surplus Administration Fee for this activity. The balance of the surplus is put back into the GRIA. Profit received from investment activities is returned to GRIA after deducting an Investment Performance Fee. The net surplus shall be shared at some predetermined ratio between participant and company. 


\section{Family Takāful Business}

Family takāful business under the wakālah model allocates contributions from participants into two separate accounts, namely the Personal Investment Account (PIA) and Personal Investment Risk Account (PRIA) at a ratio based on the various products offered. PRIA is for protection whilst PIA is for protection and investment. The company charges a wakālah fee for managing the family fund. The fee varies from product to product. Part of the contributions in PRIA and PIA will be put into the Ta 'āwun̄ , or Cooperative, Account Pool (TAP) mentioned earlier. Any surplus in TAP is put back into the respective PRIA and PIA. The company charges a Surplus Administration Fee for this activity. The balance is put back into PRIA and PIA respectively. Profit from investment activities are returned to PRIA and PIA after deducting an Investment Performance Fee. The net surplus is shared at a ratio of 50:50 or better between the participants and the company.

\section{The Wakālah-Waqf Model}

The wakālah-waqf model was started in South Africa and later copied by Pakistan's first takäful company. The main reason why the waqf element was introduced into an otherwise pure wakalah model is because of the nature of the tabarru ' fund which has a very specific use, namely to pay claims. The term tabarru' itself implies that the participant who contributes has given up his right to any claim on his contribution. This concept is akin to the concept of waqf whereby once a person declares to give away a certain property for waqf he has severed all ties to the property. Immediately the property belongs to Allah and hence a trustee has to be set up to administer the property. The same is true in this wakālah-waqf model. Once the participant declares that he has given away part of his contribution as tabarru' a trustee has to be established, in which case it is the takâful operator.

The main difference between the wakālah model and the wakālah-waqf model is the existence of the waqf fund. The waqf fund is to be used solely to pay out claims. To start the fund, the company has to pay the seed money. The fund will then be built over time through contributions made by the participants. If at any time, the fund is insufficient to cover the claims, the company will have to extend an interest-free loan which will be paid back when the fund can afford.

The participants will pay the takaful operator the contributions, based on the product taken up by the participants from among the General business. The contributions are credited to the General Takäful Fund as tabarru 'in the Participants' Special Account. Any person will be acknowledged as a member of the waqf fund if he signs the proposal form, contributes to the waqf fund and subscribes to the policy documents. 
The Waqf Fund shall work to achieve the following objectives:

- To pay compensation to its members in the event of losses, mishap or damage.

- To extend benefits to its members strictly in accordance with the Waqf Deed.

- To donate to charities approved by the Sharī ah Supervisory Board.

The Waqf Fund will lay down the rules for distribution of its funds to the beneficiaries and will decide how much compensation should be given to a subscriber or member. The waqf will become owner of all contributions and has the right to act as a legal entity as per its terms for investment, compensations and dealings with the surplus amounts.

From among the above models, the most common is now the wakālah model and some of its variants, which are being employed by almost all the new takâful operators. The mudārabah model and its variants will soon be left out as it is more advantageous for the operators to employ the wakălah model. The obvious attraction is in the wakalah fee that the company gets upfront without having to do anything else. As in the mudārabah model, the surplus may neither be shared by the participants nor by the shareholders.

The other advantage is the possibility of sharing some of the profits that have been earned through investment or even underwriting. In the above case, the company earns from both sources as a performance fee. This is indeed possible and shari 'ahcompliant, depending on how they are viewed.

\section{Future Challenges and Recommendations}

Despite the past accomplishments and strong momentum for future growth, there are at least three challenges that need to be addressed:

- The limited size and capacity. Despite relatively rapid growth, the industry is still very small compared to the conventional insurance market. In 2006, participants' contributions stood at US\$2 billion, accounting for only 1 per cent of the US\$3.7 trillion global insurance premiums. The takâful assets are estimated to be around US\$20 billion, in contrast to the Islamic banking assets of US\$500 billion. The takâful sector grows at a relatively slower pace than the sukük market which is growing at about 40 per cent. Takäful players are relatively small with the largest takäful company having total assets of only US\$3 billion. Being young and new, many takäful operators also lack capacity, capabilities and expertise to manage businesses with large and complex risks. ${ }^{21}$ 
- The low penetration rate. Although Muslims account for at least 22 per cent of the world's population, takâful contribution in Muslim countries constitutes only 1 per cent of the total global insurance premium. This shows the potential for a strong demand for takâful products and services within the Muslim world if only they view takâful protection as an important tool for risk mitigation. ${ }^{22}$

- The lack of 're-takāful' support and capacity. Adequate support from strong 're-takâful' companies is vital for the takāful sector in risk mitigation, capital relief provision, and building of essential technical capabilities in managing risks. Currently there are about 10 to 15 're-takâful' companies available to support over 250 takāful operators worldwide. ${ }^{23}$ Until now, most takāful and even the 're-takâful' operators have to depend on conventional reinsurers. This does not augur well with the need to cater for the unique principles of takāful products.

A number of strategies can be considered for planning and implementation:

- There is a strong need to build a more globalised takāful industry through greater connectivity across jurisdictions. Takāful operators need to give sufficient emphasis on cross-border linkages at regional and international levels. This will not only widen the market but more importantly bring exposure to the different challenges to build strength and competitiveness.

- Efforts towards concerted branding for takāful have to be initiated and developed. By concerted branding we could enhance the appeal of takāful to the global community. The takâful principles of mutuality, transparency and cooperation could be further popularised to spearhead unique products for the global community.

- We have to position the sharī 'ah as an enabler for greater linkages of takäful markets globally. Research and training in the sharì' $a$ h and sharī'ah-related issues and fields may be one approach to spread the influence of the shari ${ }^{-} a h$ and takâful in all markets that takâful can serve. Acute shortage of human talent cannot be ignored at all.

- Takäful, as is the case with any business that deals with a huge number of clients, must be well-equipped with infrastructure that could help expedite processes and improve accuracy to mitigate risks in these areas. It is not only the physical infrastructures including IT that are needed, but also the regulatory framework must be further strengthened.

- Takāful should not be looked at merely as a business concern but should also locate areas where socio-economic assistance is definitely needed. Corporate Social Responsibility could be employed as a means of reaching out to assist in the community improvement. 
To conclude, the future of takäful is not bleak at all. Indeed it is very bright. Within a short span of 30 years or so, takâful has become a growing force in financial circles. However, it requires not just the operators, but also the combined efforts of all the relevant parties - the regulators, market participants, shari ' $a h$-experts and the international community at large - to play their roles.

\section{Notes}

1. Keynote Address by Muhammad bin Ibrahim at the International Takāful Summit, "Global Takāful Industry: Moving to the Next Level of Excellence", Jumeirah Carlton Hotel, London, 16 July 2008.

2. Ibid., 1 .

3. Ibid., 2.

4. Ibid.

5. Muhammad Muslehuddin, Insurance and Islamic Law (Lahore: Islamic Publications, 1969), 15.

6. James Biggs Porter, William Feilden Craies, and T.W. Morgan, The Laws of Insurance. Fire, Life, Accident, and Guarantee, Embodying Cases in the English, Scotch, Irish, American, Australian, and Canadian Courts (London: Sweet and Maxwell, 1933, 8th ed.), 47.

7. Afzalur Rahman, Economic Doctrines of Islam, 4 vols (London: The Muslim Schools Trust, 1979), 4:65-9.

8. Qur'ān 2:178. See also ibid., 4:91.

9. Ibid., 5:48.

10. M.M. Billah, Applied Islamic Law of Trade and Finance (Petaling Jaya: Sweet and Maxwell Asia, 2007, 3rd ed.), 125-200.

11. Șahịh Muslim, "Kitāb al-Birr", hadīth no. 59.

12. Philip K. Hitti, Makers of Arab History (London: Macmillan, 1969), 69-71.

13. Qur'ān 5:2 (tr. Yusuf Ali).

14. Narrated by Imām Aḥmad Ibn Ḥanbal and Imām Abū Dāud.

15. Narrated by Imām al-Bukhārī and Imām Muslim.

16. Narrated by Imām al-Bukhārī and Imām Muslim.

17. Narrated by Imām Aḥmad Ibn Ḥanbal.

18. Narrated by Imām Aḥmad Ibn Ḥanbal; see also Sahịḥ Muslim, "Kitāb al-Birr", hadīth no. 984.

19. Sahịhh Muslim, "Kitāb al-Birr", hadīth no. 59.

20. Qur'ān 5:2.

21. Muhammad bin Ibrahim, "Global Takāful Industry", 2.

22. Ibid., 3 .

23. Ibid 